\title{
A STRANGER IN ONE'S OWN HOME: SurveillanCE, SPACE, PlaCe, AND EMOTION DURING THE GAM CONFLICT IN ACEH
}

\section{Catherine Smith}

This article examines some of the implications of the surveillance strategy known as "sweeping," which was a common form of surveillance used by the Indonesian security forces during the conflict between the Free Aceh Movement (Gerakan Aceh Merdeka, GAM) and the Government of Indonesia. ${ }^{1}$ During this thirty-year conflict (1976-2005), GAM fought for Acehnese independence from Indonesia. GAM originally protested the economic exploitation of Aceh's oil and gas reserves.2 They further claimed that this economic exploitation was a betrayal of Aceh by the state, and a refusal of the state to recognize Aceh's distinct regional identity, which GAM leaders saw as grounded in Aceh's precolonial history as an influential power within the

Catherine Smith, a visiting fellow in the Department of Political and Social Change, Australian National University, thanks Annie Pohlman, Jane Palmer, Lucy Fraser, Victor Igreja, and Ed Aspinall for their insightful comments on earlier drafts of this article, and she gratefully acknowledges the Asian Studies Association of Australia (ASAA) for funding the writing of this article.

${ }^{1}$ Note that the English term "sweeping" is widely incorporated into everyday discourse in post-conflict Aceh.

2 Timothy Kell, The Roots of Acehnese Rebellion 1989-1992 (Ithaca: Cornell University Press, 1995). 
region. ${ }^{3}$ As we will see, the central government responded to GAM through a military campaign that involved the use of widespread terror, violence, and surveillance, not only against GAM fighters, but against many Acehnese civilians. The conflict was eventually resolved in August 2005 through a peace agreement. Although the conflict survivors I interviewed in 2008 and 2009 had experienced multiple forms of political and structural violence, I found that many repeatedly returned to the topic of sweeping when discussing a wide range of other conflict experiences.

The term "sweeping" refers to two distinct but interconnected modes of surveillance: roadblocks, which acted as military checkpoints while also restricting people's daily mobility and isolating particular towns; and door-to-door checks, in which soldiers entered people's homes, searched for rebels, and questioned ordinary Acehnese about their knowledge of rebel activity. Ostensibly a means to gather information on GAM fighters, sweeping came to have a wide range of effects on the everyday lives of Acehnese, and on the dynamics of the conflict. Through sweeping, the Indonesian security forces divided the Acehnese landscape into zones and erected roadblocks at which people were routinely stopped, asked to show their identity cards, and questioned. Sweeping was often accompanied by other forms of intimidation, as people were frequently interrogated, harassed, threatened with violence, and sometimes beaten at checkpoints. They were routinely questioned about their movements, interrogated about their knowledge of rebel activity, pressured to inform on their neighbors, and sometimes asked to declare their loyalty to the state. Extortion and the destruction of property were common. Many conflict survivors told me how sweeping contributed to the breakdown of local economies, as the mobility restrictions made it difficult and dangerous for farmers to go to the rice fields and plantations, and for small traders to move about to market towns to buy and sell their wares.

The significance that sweeping played within the conflict is reflected in the prominence that my interlocutors gave to sweeping in their life histories. During the seventeen months of ethnographic fieldwork I carried out in 2008 and 2009, I lived in Banda Aceh and traveled throughout Aceh, taking the life histories of fifty-three women conflict survivors and carrying out other interviews and ethnographic fieldwork. My fieldwork took place several years after the conflict had been resolved and during a period of transition in which Aceh was seen to be opening to the world. The timing of my fieldwork meant that my respondents felt safe enough to narrate their life experiences and were often eager to do so, usually for the first time. I worked primarily with women conflict survivors living along Aceh's north coast districts, including Pidie, Bireuen, and North Aceh, and conflict survivors living in Aceh Besar, the district surrounding the provincial capital Banda Aceh. I also interviewed many families who had moved between several conflict-affected districts, including some who had moved to Banda Aceh from various rural areas in an attempt to escape the conflict. My research focused on women's experiences of conflict-related trauma and trauma healing, although I also spent extensive time with whole families and interviewed the male relatives and neighbors of my key respondents. While many of the north coast districts were strongly affected by sweeping for long periodsd, I found that even in areas where the experience of direct conflict was of a shorter duration, that

${ }^{3}$ Edward Aspinall, "Modernity, History, and Ethnicity: Indonesian and Acehnese nationalism in conflict," RIMA 36, no. 1 (2002): 3-33. 
it was also very common for my respondents to draw attention to sweeping as a mode of violence that had a profound impact on their lives. In my interviews, I found that people frequently emphasized sweeping as a form of intrusion and a major disruptive force on their lives and communities during the conflict, including when discussing experiences that at first seemed more shocking and destructive to me.

My motivation in writing this article is firstly to acknowledge that sweeping was a common conflict experience that was widely protested by conflict survivors in the post-conflict period, and that should become part of broader accounts of the conflict. Many remembered the conflict as being characterized by years of continual threats, intrusion, intimidation, and extortion that were greatly exacerbated by growing poverty and the gradual breakdown of local economies, and punctuated by acts of extreme violence and suffering, such as killings and torture. Although human rights groups often give primary focus to gross violations of human rights and pay only marginal attention to "low-level" forms of violence, such as surveillance and intimidation, many anthropologists have found that protracted low-level violence has a meaningful impact on people's lives. ${ }^{4}$

In addition, I argue that sweeping reveals much about the broader dynamics of the conflict as it transformed over time and operated in differentiated social spaces. In particular, sweeping illustrates how surveillance shaped the spatial-temporal dynamics of this sporadic conflict as it fluctuated over time, and as new segments of Acehnese society became wound up in the conflict. The spatial-temporal effects of sweeping directly shaped the affective climate of the conflict by creating a general atmosphere of suspicion within the areas demarcated as the conflict zone, and by creating localized affective communities within particular microlocalities. Here I contribute to a rich body of anthropological research on surveillance and terror that demonstrates that surveillance is not only a technique through which security forces gather information, but a mode of terror that works to militarize social space and shape the affective climate of everyday life..$^{5}$

The article illustrates how the security forces deployed sweeping as a strategy to militarize social space on both the macro and the micro levels. As sweeping demarcated the boundaries of the conflict zone, it created a generalized climate of fear, uncertainty, and suspicion throughout regions in which sweeping was a visible feature of the landscape at a particular point in time. This generalized affective climate was not constant, but fluctuated as the conflict continually intensified and eased over time, and as the boundaries of the conflict zone shifted. Within this fluctuating affective climate, sweeping created localized affective communities in microlocalities that were

\footnotetext{
${ }^{4}$ For example, see Fiona C. Ross, Bearing Witness: Women and the Truth and Reconciliation Commission in South Africa (London: Pluto Press, 2003). Ross points out that the emphasis that transitional justice mechanisms give to physical violence inadvertently privileges certain forms of violence and forms of witnessing over others. I am not saying that surveillance or fear are worse than gross human rights violations, but simply that these modalities of violence significantly impacted people's lives and the overall conflict dynamics.

${ }^{5}$ For example: Allen Feldman, Formations of Violence: The Narratioe of the Body and Political Terror in Northern Ireland (Chicago and London: University of Chicago Press, 1991); Linda Green, "Fear as a Way of Life," Cultural Anthropology 9, no.2 (1994): 227-56; Antonius C. G. M. Robben, Political Violence and Trauma in Argentina (Philadelphia: University of Pennsylvania Press, 2005); and Monique Skidmore, Karaoke Fascism: Burma and the Politics of Fear (Philadelphia: University of Pennsylvania Press, 2004).
} 
frequently subjected to sweeping and that, therefore, came to be seen as especially dangerous or suspected places. These localized affective communities were characterized by a range of emotions, including extreme fear, but also more subtle emotional states. Although the heightened surveillance of microlocalities did generate terror, it also heightened empathy and solidarity within those communities. Many conflict survivors were vigilant at observing shifts in the affective climate, so that this shifting emotional landscape helped to guide conflict survivors as they attempted to navigate everyday life in a militarized but continually changing conflict environment.

The article begins by describing the imagined political geography that informed the practice of sweeping and that, when combined with other forms of violence, ultimately came to visually demarcate the area that came to be known as "the conflict zone." The zoning mentality that underpinned sweeping drew from and reinforced much older tropes about the rural countryside and the mountains as sites of Acehnese rebellion. ${ }^{6} \mathrm{I}$ argue that more than perpetuating narratives about the people who inhabited these spaces, sweeping worked as a spatializing practice that transformed the space of

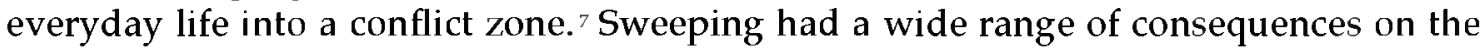
macro level, including naturalizing the perceived boundaries of the conflict zone. On the micro level, sweeping transformed everyday places into spaces of threats and imminent danger, especially in areas that came to be known as "black zones."

The spatializing effects of sweeping worked to created localized affective climates within these militarized spaces. In many cases, sweeping generated high levels of terror, especially in black zones and during peak periods of conflict. However, feelings of extreme fear and terror did not always dominate social life, undermine social interactions, or interrupt the ability of conflict survivors to navigate the conflict environment. Rather, the affective climate of the conflict varied significantly across space, and continually shifted with changes in the overall conflict dynamics. While sweeping, and the conflict in general, did engender terror and greatly destabilize social life, it also generated a wide range of emotional experiences that shaped my contributors' responses to the conflict in various ways. In particular, sweeping was closely related to widespread feelings of being suspected (dicurigai), and a sense of feeling tidak betah ("not feeling in place at home anymore") that resulted from the constant intrusion of security forces into everyday life. At the same time, surveillance inadvertently reaffirmed feelings of being close (akrab), proud (bangga), strong (kuat), and brave (berani), and a sense of being of the same destiny (senasib) as other Acehnese living in the conflict zone. Sweeping enabled conflict survivors to interpret the conflict landscape and navigate everyday life in a militarized but continually shifting environment. Although the security forces employed sweeping to control people's movement through space and to undermine Acehnese solidarity by interrupting everyday social interactions, in practice the effects of sweeping were more ambiguous. Surveillance produced a broad range of affective responses to conflict that acted

\footnotetext{
"See Edward Aspinall, "Place and Displacement in the Aceh Conflict," in Conflict, Violence, and Displacement in Indonesia, ed. Eva-Lotta Hedman (Ithaca: Cornell Southeast Asia Program Publications, 2008), 119-46.

${ }^{7}$ See also: Feldman, Formations of Violence; Green, "Fear as a Way of Life"; and Monique Skidmore, "Darker than Midnight: Fear, Vulnerability and Terror Making in Urban Burma," American Ethnologist 30, no. 1 (2003): 5-21.
} 
alongside fear to shape everyday responses to conflict. As such, I conclude that although sweeping was destructive, it ultimately failed as a military strategy.

\section{Imagining Rural Aceh as a Space of Rebellion}

Perhaps the most dramatic spatial effect of sweeping on the macro level was that it came to demarcate the boundaries of what became known as the conflict zone. GAM had its origins and a significant popular support base in many rural, north coast areas. However, the narratives that associated Acehnese rebellion with the rural landscape did not simply describe the geographical distribution of the conflict. Rather, these conflict narratives worked to shape the dynamics of the conflict as it shifted over time and expanded to incorporate new villages and districts. The perception of rural Aceh as a space of rebellion drew from much older narratives about Acehnese rebellion that associate Acehnese bravery with the mountains, the jungle, and rural life. The state has long represented Aceh as a wild and ungovernable frontier and Acehnese people as stubborn and violent rebels. ${ }^{8}$ These representations of Aceh drew strongly from narratives about Aceh's long war of resistance against Dutch colonial forces, particularly during the later phases of this resistance when Acehnese rebels retreated into the jungle and continued a sporadic war of guerrilla resistance. ${ }^{9}$ Although the Acehnese historically lived in the coastal areas while the mountainous interior was considered the home of Aceh's other ethnic groups (especially the Gayo and the Alas peoples), narratives promoted by both the security forces and GAM strongly associate Acehnese rebellion with the mountains, rice fields, traditional wooden houses, and rural spaces more generally.

Aspinall has demonstrated that the forced displacement of populations was intimately connected to the ways in which GAM and the security forces imagined space and sought to gain control over rural Aceh. ${ }^{10}$ Aspinall illustrates that forced displacement was not an unintended consequence, but a strategy taken up by the security forces in their attempts to control Aceh's largely rural and mountainous landscape. On a much smaller scale, GAM displaced Javanese living in Aceh through direct violence and through aggressive ethnonationalist discourses that claimed the Acehnese territory as a homeland. At the same time, the security forces intentionally displaced large numbers of Acehnese in an attempt to separate GAM fighters from their rural popular support base.11 Aspinall quotes Lieutenant General Sudi Silalahi, then coordinating minister for political and security affairs, as saying:

First we will ask women and children to leave their houses. Then we will ask unarmed men to do the same. The ones left behind must be those with arms. ${ }^{12}$

\footnotetext{
${ }^{8}$ Aspinall, "Modernity, History, and Ethnicity."

${ }^{9}$ Anthony Reid, The Blood of the People: Reoolution and the End of Traditional Rule in Northern Sumatr. (Kuala Lumpur: Oxford University Press, 1979).

${ }^{10}$ Aspinall, "Place and Displacement in the Aceh Conflict," 121-25.

11 Ibid., 143.

${ }^{12}$ Cited in Aspinall, "Place and Displacement in the Aceh Conflict," 143.
} 
The security forces saw the mountains, foothills, and the rural Acehnese landscape in general as a haven for GAM rebels. The security forces took up the seemingly impossible task of scouring the jungle for GAM fighters on foot, while GAM leaders remained aware of the advantage given to them by the mountainous landscape.

There is no question that the strong association between GAM and the rural landscape has also been cultivated by the stories GAM fighters tell about themselves. Former combatants often tell intriguing stories of being led through the jungle to safety by tigers, snakes, and other wild animals that acted, in various ways, as guardians. Some explain how tigers would use their claws to mark a cross in a track, which was seen to indicate the path to safety. ${ }^{13}$ Narratives about GAM often describe fighters as having special powers, such as rebels who were said to outsmart the security forces by learning how to breathe underwater and hide on the bottom of rivers, who were able to control the minds of soldiers in order to walk through military checkpoints without being noticed, or who were able to kill their enemies simply by cutting branches off a tree. ${ }^{14}$ Even my interlocutors who strongly disliked GAM often expressed admiration at the way that fighters used magic to make themselves invulnerable to bullets and to perform acts of magic and trickery against authorities. ${ }^{15}$ Ex-combatants often present their practical skills and knowledge of the landscape as a form of trickery itself, and often boast of their ability to find good hideouts and to navigate the difficult terrain far more skillfully than their opponents in the security forces.16 Stories about Aceh's esteemed women combatants-inong bale-are often romanticized tales of resistance in the mountains. One young woman in Banda Aceh once told me that:

In Aceh, we say that fighters are like orchids. They grow in the mountains and they only need to breathe air to live. Even now the old women in the villages mix orchids in coconut oil and put the oil in their hair. The fragrance from the orchids reminds them of Cut Nyak Dien, ${ }^{17}$ reminds them that they are Acehnese.

These resistance stories were widely circulated throughout Acehnese society, and I found people immensely enjoyed both hearing and telling these stories. Many of my respondents narrated this mystical connection between GAM fighters and the jungle with pleasure and pride, since admiring the bravery of others and telling stories of survival is a powerful source of resilience, and a common rhetorical practice used in everyday life to generate valued states of being strong (kuat), tranquil (tenang), and brave (berani). These stories associating GAM with the landscape served an important narrative function in generating everyday resilience and in reclaiming rural Aceh as a familiar social space, even as the security forces attempted to militarize and occupy the rural landscape.

\footnotetext{
${ }^{13}$ Edward Aspinall, Islam and Nation: Separatist Rebellion in Aceh, Indonesia (Stanford: Stanford University Press, 2009).

14 Personal correspondence with Roman Patock, March 25, 2015.

${ }^{15}$ On notions of trickery within Acehnese resistance, see Jacqueline Aquino Siapno, Gender, Islam, Nationalism, and the State in Aceh: The Paradox of Power, Co-optation and Resistance (London: Routledge Curzon, 2002), 10-11, 16.

${ }^{16}$ Aspinall, Islam and Nation, 65-68, 89, 94-95.

${ }^{17}$ Cut Nyak Dien is a celebrated Acehnese woman who fought against Dutch colonial aggression alongside her husband and then after his death (see Siapno, Gender, Islam, Nationalism, and the State in Aceh, 25-26).
} 
However, not all of the conflict survivors I interviewed were able to enjoy these resistance stories. Quite a few described the mountains as a precarious place of relative safety that was also dangerous and full of hardship. To many, the mountains were a place of safety to flee to when the aparat (security forces) entered their villages. Several of my interlocutors fled to the mountains in fear after particularly frightening experiences of threats and questioning, or after attacks on their villages. Often these mountains were foothills a few kilometers from the villages, though some villagers ventured much further afield to safety. Many vividly described getting lost or feeling frightened or confused in the jungle, feeling tired from walking through difficult terrain, being hungry and thirsty, and being bitten by mosquitoes or caught in heavy rain.

Many who remembered the bitter realities of life in the jungle were less able to share in the pleasure of the narratives of the mountains as a place of mystical protection. For instance, one of my interlocutors, Fatimah, was a GAM woman who was loved and respected in her village for her bravery and endurance at having survived time alone in the jungle and many other forms of hardship. She once told me a sad but fascinating story of getting lost in the jungle after fleeing a military attack. She tied herself to branches high in a tree, and was protected by a tiger that stood at the base of the tree and guarded her while she slept. Some of her neighbors were present at our conversation and very much enjoyed her story, pointing out to me her bravery and cunning at being able to survive in the mountains. Later, when we were alone, Fatimah turned to me and said:

They don't know, they don't know ... they don't know what it is to be alone in the jungle. Never mind, [we feel] solidarity [akrab] in [my village]. The people here [pointing around], they look after me, they always give me rice. During the conflict, if somebody came looking for me, they always said they didn't know where I was. There are often kenduri (ritual feasts) in this village. We look after each other. We are $a k r a b$ [close] here.

Although sweeping was informed by broad cultural narratives about the rural landscape as a source of rebellion and resilience, the practice of surveillance itself worked to demarcate rural Aceh physically as a site of suspicion. As Aretxaga points out, the practices and discourses that generate terror usually "resonate with existing genres and forms of emplotment." 18 It is this familiarity that gives terror both force and an appearance of truth. Narratives about survival in the mountains are widely circulated, as many Acehnese enjoy narrating stories that build a sense of shared strength and bravery. ${ }^{19}$ Once incorporated into conflict strategies, however, this same imagining of rebellion and the landscape worked to naturalize the boundaries of the conflict zone and mark the boundaries of the conflict into everyday social space.

\footnotetext{
${ }^{18}$ Begoña Aretxaga, "A Fictional Reality: Paramilitary Death Squads and the Construction of State Terror in Spain," in Death Squad: The Anthropology of State Terror, ed. Jeffrey A. Sluka (Philadelphia: University of Pennsylvania Press, 2000), 46.

${ }^{19}$ Drexler is cautious of narratives that emphasize Aceh's history of conflict, arguing that they worked to perpetuate the conflict. See Elizabeth F Drexler, "The Social Life of Conflict Narratives: Violent Antagonists, Imagined Histories, and Foreclosed Futures in Aceh, Indonesia," Anthropological Quarterly 80 , no. 4 (2007): 961-95.
} 


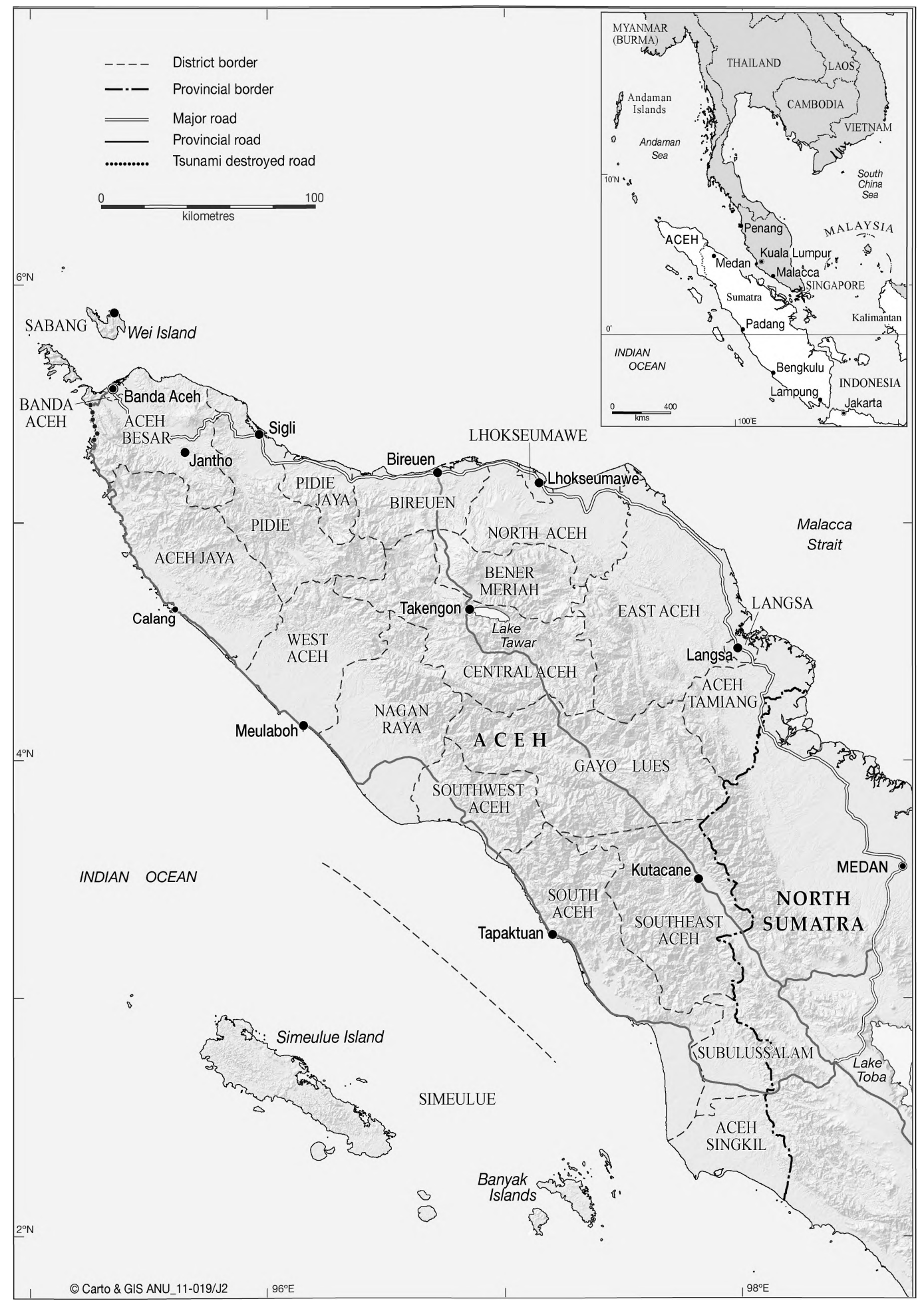

Map One: Province of Aceh showing district boundaries

Source: CartoGIS, College of Asia and the Pacific, the Australian National University 


\section{Sweeping and the Beginnings of the Conflict}

At the start of the conflict, this association between rebellion and the rural landscape led to the targeting of rural villages along Aceh's north coast, although the spatial distribution of the conflict went on to change greatly over the nearly thirty-year duration of the conflict. The roots of the conflict are closely associated with the districts of Pidie and North Aceh. Much military attention focused on the township of Lhokseumawe-the center of Aceh's disputed oil and gas complex-and the villages connected to Lhokseumawe through trade and family ties. It was in the districts of Pidie and North Aceh that GAM originally formed in the late 1970s, although during this time Aceh Merdeka (Free Aceh) was restricted to a relatively limited network of families. As Aspinall illustrates, while GAM remained relatively dormant for many years after its initial formation in the late 1970s, bonds among GAM families across the north coast districts strengthened over time, and these family connections played an important role in facilitating the development of GAM as an armed guerilla movement. ${ }^{20}$

In 1989, Aceh Merdeka reemerged as Gerakan Aceh Merdeka, launching a series of attacks on military posts and protesting the exploitation of Aceh's oil and gas reserves. ${ }^{21}$ In 1990, the central government responded by deploying five thousand additional soldiers to Aceh, bringing the number of troops stationed within the province to twelve thousand, compared to an estimated two hundred armed rebels.22 The security forces then referred to GAM as the GPK (Gerombolan Pengacau Keamanan, Gang of Security Disruptors), a discourse that was used elsewhere by the New Order government in the 1990s to enforce compliance to the state by evoking fear of the otherwise unnamed "security disruptors." ${ }^{23}$ In mid-1990, the security forces announced their intention of "crushing" the movement by the end of that year through military force. ${ }^{24}$ These additional soldiers became a visible feature of Aceh's sparsely populated, rural landscape. They made their presence known through a widespread terror campaign that was aimed at civilians, and that became widely known as DOM (Daerah

\footnotetext{
${ }^{20}$ Aspinall, Islam and Nation, 88-95.

${ }_{21}$ On natural resource exploitation as a contributing cause of the conflict, see Kell, The Roots of Acehnese Rebellion 1989-1992; Lesley McCulloch, Greed: The Silent Force of the Conflict in Aceh (Melbourne: Deakin University, 2003); and Siapno, Gender, Islam, Nationalism, and the State in Aceh, 43-49. On the involvement of ExxonMobil in gross human rights violations committed by the security forces, see Ross Clarke (on behalf of ICTJ, HRWG, Imparsial, and Kontras), A Matter of Complicity? Exxon Mobil on Trial for Its Role in Human Rights Violations in Aceh (International Centre for Transitional Justice, Case Study Series, 2008), available at: https:/ / www.ictj.org/ sites/default/ files/ICTJ-Indonesia-Aceh-Exxon-2008-English.pdf, accessed September 14, 2015.

${ }^{22}$ Geoffrey Robinson, "Rawan is as Rawan Does: The Origins of Disorder in New Order Aceh," Indonesia 66, (1998): 131

23 See: Ibid., 143; Aspinall, Islam and Nation, 111; and Siapno, "Gender, Islam, Nationalism, and the State in Aceh, 29. Note that Drexler argues to the contrary that it is problematic to differentiate between GAM as a political movement and GPK as a criminal movement. See Elizabeth Drexler, "History and Liability in Aceh: Single Bad Guys and Convergent Narratives," American Ethnologist 33, no. 3 (August 2006), 313-26. On discourses of criminality within New Order terror, see Joshua Barker, "State of Fear: Controlling the Criminal Contagion in Suharto's New Order," Indonesia 66 (October 1998): 7-42.
}

${ }^{24}$ Amnesty International, "Indonesia: 'Shock Therapy': Restoring Order in Aceh 1989-1993," Amnesty International document, July 27, 1993: 10-11, available at https:// www.amnesty.org/ en/ documents/ ASA21/007/1993/en/, accessed September 14, 2015. 
Operasi Militer, Military Operations Zone). DOM was targeted at rural communities in North Aceh, Pidie, and East Aceh.

Human rights organizations have documented a wide range of human rights violations committed during DOM, especially during the early 1990s. These include the burning of houses, arbitrary arrests and detentions, the forcible use of civilians to search for suspected rebels, summary executions, torture, rape, abductions, and many other acts of violence. ${ }^{25}$ While Aceh did not have a large, organized militia (comparable to Timor Leste for example), the security forces attempted to create a militia through organizing rallies and encouraging vigilante violence against those suspected of being sympathetic to GAM.26 Amnesty International quotes a statement Regional Military Commander Major General H. R. Promono made to a journalist in November 1990:

I have told the community, if you find a terrorist, kill him. There's no need to investigate him. Don't let people be the victims. If they don't do as you order them, shoot them on the spot, or butcher them. I tell members of the community to carry sharp weapons, a machete or whatever. If you meet a terrorist, kill him. ${ }^{27}$

Siapno recalls that wanted posters for "GPK terrorists" were prominent during her fieldwork in the 1990s, and notes that these posters inspired both widespread fear and indignation. ${ }^{x}$ Later in 2008 and 2009, many of my interlocutors still recalled how the bullying tactics of the security forces generated widespread fear, while also greatly reducing the credibility of the security forces. These responses intensified as violent conflict began to escalate and the state increasingly began to intrude into everyday life. Sweeping became a common form of intrusion by the state, as security forces increasingly carried out intimidating door-to-door checks and began to erect roadblocks at which people were often questioned, threatened, beaten, and extorted for money. These roadblocks inhibited the ability of many Acehnese to travel to fields to work and to neighboring towns to shop, trade, and visit family. This irritated people, exacerbated poverty, and made it increasingly difficult for people living in areas affected by sweeping to avoid becoming entangled in the conflict, including those who were not otherwise interested in politics.

\section{Intensifying the Conflict Zone-Times and Spaces of Heightened Terror}

This intrusion into everyday life did not occur instantly or uniformly across space, but fluctuated throughout the course of the conflict, and at times became concentrated in particular communities, some of which later became known as "black zones." Large scale mapping of conflict-related violence in the post-conflict period later revealed that

\footnotetext{
${ }^{25}$ Ibid. On DOM, see also Robinson, "Rawan is as Rawan Does," 143. For a mapping of violence over the full duration of the conflict, see Byron Good, Mary-Jo DelVecchio Good, Jesse Grayman, and Matthew Lakoma, A Psychosocial Needs Assessment of Communities Affected by the Conflicts in the Districts of Pidie, Bireuen, and Aceh Utara (Geneva: Harvard Medical School and International Organization for Migration, 2006).

${ }^{26}$ Amnesty International, "Indonesia: 'Shock Therapy,'" 12-15.

${ }^{27}$ Ibid., 15.

${ }^{28}$ Siapno, Gender, Islam, Nationalism, and the State in Aceh, xii, 29.
} 
while violence was much more widespread and of a higher intensity than was previously expected, certain microlocalities (villages, roads, fields, or intersections) suffered much higher levels of violence than nearby localities. ${ }^{\star}$ Although this zoning mentality was not bureaucratized by the security forces until the military emergency in 2003-when the security forces officially divided Aceh into black, grey, and white zones-the practice of targeting particular villages and microlocalities began during DOM.

The early 1990s saw a period of intensified violence in rural Aceh, including the rise of all manner of intimidation. The security forces carried out sweeping through door-to-door checks of houses, often late at night. Soldiers frequently aggressively accused people of complicity with GAM, searched their houses, and demanded that they turn over GAM fighters and inform on their neighbors and family. Many people described to me the terror they felt when armed soldiers burst into their houses in the middle of the night. For example, Shadiah, an elderly woman from a village in Pidie, described to me how soldiers often came into her house at night to accuse her of giving rice to GAM fighters. The soldiers would run through her old timber house still wearing their heavy boots. She mimicked the sound of heavy boots running across old timber floors-"Boom! Boom! Boom!"-and gestured with her hands as if soldiers were reaching out and shaking her house. "Who can feel in place at home (betah) when you have arrogant soldiers entering your home in the middle of the night?!" Likewise, others had loved ones taken from their houses in the middle of the night (ambil malam). Some were returned bruised and beaten, while others never returned.

It was during the early years of DOM that the security forces began to display corpses at intersections, leaning against fences, hanging from trees, or in shallow graves at the side of the road..$^{\circ}$ As Barker illustrates, this same grotesque practice was used by the New Order government in other parts of Indonesia to generate widespread fear and suspicion throughout Indonesian society, and in an attempt to produce an emotional reliance on the state as the sole source of social order." Similar practices have been used by military regimes in many countries. As Feldman has illustrated for Northern Ireland, the display of corpses as a terror strategy not only adds enormously to the climate of fear within an escalating conflict, but also carries dramatic effects on the spatial and temporal experience of violent conflict. ${ }^{.2}$ Feldman argues that through public assassinations and the display of corpses, conflict protagonists not only attempt to claim control of social space but also to resignify

\footnotetext{
${ }^{29}$ Byron Good, Mary-Jo DelVecchio Good, Jesse Grayman, and Matthew Lakoma, A Psychosocial Needs Assessment of Communities in 14 Conflict-affected Districts in Aceh (Geneva: Harvard Medical School and International Organization for Migration, 2007), 3-7.

30 See also Robinson, "Rawan is as Rawan Does," 142, 146.

${ }^{31}$ Barker, "State of Fear." Robinson points out that many of the terror strategies used by the security forces in Aceh were "tested" in East Timor and then transported to Aceh (see Robinson, "Rawan is as Rawan Does," 146). Note, however, that my interlocutors did not describe corpse display as a widely used strategy of the Indonesian government, but rather as a feature of DOM, which most in turn located within a much longer history of external intrusion into Aceh. While it is possible and valid to interpret the conflict in Aceh in terms of broader Indonesian political history, I give preference to my interlocutors' interpretations of Aceh's history of conflict and have attempted to avoid writing a Jakarta-centric account of the oppression of Aceh. (See also Siapno, Gender, Islam, Nationalism, and the State in Aceh.)

32 Feldman, Formations of Violence.
} 
particular social spaces, and the corpses themselves, into signs of a military regime. In Aceh, too, the public display of corpses worked not only to terrify and distress ordinary Acehnese, but also to transform ordinary social spaces into places of potential danger, and to mark times and spaces of conflict into the patterns of everyday life.

Over time, DOM spread across the north coast districts and East Aceh, although certain places suffered much higher levels of violence than did nearby locations. The most dangerous places later came to be known as "black zones," and it was widely understood that to live in or travel through a black zone would likely result in being "suspected" or being "taken." My interlocutors who had lived in a black zone remember intense violence, heightened terror, and a sense of feeling regularly targeted by the security forces. One example of a well-known black zone is a village in rural Pidie that the security forces referred to by the somewhat cruel nickname "the hill of widows" (bukit janda). When I visited the village in 2008 and carried out short interviews with several women, they were quick to tell me that, in fact, they were not all widows, although many people from that village had been killed during the conflict. This village has become well known in Aceh, and to many other Acehnese the name bukit janda has come to signify the bravery of Acehnese widows. And, indeed, the women I interviewed in this village were impressively brave. However, the name bukit janda was coined by soldiers as a means to taunt the town, and this naming can be seen in and of itself an act of violence against the village. The women told me that the soldiers named the village "the Hill of Widows" after many of their husbands fled to the mountains or the west coast after being tortured, detained, or threatened. The cruel naming of the village suggested to men that they no longer played a role in village life, and to women that their husbands were dead. The women explained to me that once many of their husbands had left, this in turn became an opportunity for soldiers to further harass and threaten the women, coming into their homes nightly and telling them that their husbands were dead, then immediately interrogating them for information on their husbands' whereabouts. As the nickname "Hill of Widows" suggests, this village is located near a small foothill and can be accessed only by a narrow dirt road. Sweeping was a near-permanent feature along this small road, effectively making it impossible for people to enter or leave without passing through a military checkpoint. Sweeping often worked to physically isolate villages, and this relative isolation was perceived to intensify the many forms of violence inflicted against such communities.

Another of my respondents, Safrina, grew up in a village in rural North Aceh that later became known as a black zone. While the whole district of North Aceh was considered an area sympathetic to GAM, Safrina felt that her village was particularly targeted by the state. Indeed, Safrina's village was subjected to a number of attacks, including at least one incident when security forces drove through town and opened fire, killing and wounding a number of people. However, it was not these killings that Safrina emphasized in her life history. Rather, many of her stories were associated with the narrow dirt road that connected her village to the main road. Safrina recalled the abduction of people traveling along the road, the display of corpses along that road, and the heightened fear that permeated village life as a result.

During DOM, sweeping became so common on the dirt road into her village that minivans stopped running to her village, and it became isolated from the neighboring 
villages, the main road, and the nearby market town. The road to her village became dangerous, and people were often stopped, interrogated, threatened, and extorted when traveling to the next village or the nearby town. Safrina recalls that people were taken when traveling along that dirt road. Minivan drivers stopped driving to her village, since this road came to be seen as a black zone from which people disappeared and that was known to be subjected to frequent roadblocks and sweeping. Once the minivans stopped traveling to her village, Safrina and the other children in her village needed to walk to the next village every day to go to school.

Safrina had strong recollections of passing corpses as she walked to school. Some were bound and gagged. Some lay on the side of the road in shallow graves, their faces partly visible. Others were hanging from trees or leaning against fences.

I had to walk to school. There was no teacher in our village, so I had to walk far to the next village to go to school. Every day I passed corpses. Every day there were corpses, on the side of the road, hanging from trees, against fences. Sometimes they were in strange positions, so it was difficult to know- "What is it? Is it a person?" But it was, indeed, a person, a corpse. Some had their faces partly covered with dirt, so it was difficult to recognize them. It often made me think, "Who is this person? Is it somebody I know? Is it somebody from our village or an outsider?" I wanted to look to see if the person was from our village, but at the same time I didn't want to look. I remember that feeling, wanting to look, but not wanting to look ... ahhhh. It made me imagine the family of that person, what they must be feeling, if they want revenge, if they are strong or weak, alone or together, if they have trauma.

Safrina understood the display of corpses as a sign that her village was targeted, and recalled the combination of fear and empathic imagining that she felt when she encountered a corpse and wondered who the victim was, and what that person's family might be feeling. Later in her life, this empathic imagining made her very cautious of GAM rebels, who she felt must be feeling anger (marah) and revenge (dendam) after having been witness to so many traumatic experiences. At the same time, Safrina greatly admired many conflict victims (korban) for being brave, patient (sabar), and clever (pandai), and for surviving great adversity.

Safrina described the fear that permeated her targeted village when she was young, as a result of the extreme violence in the area coupled with the constant surveillance villagers faced:

When I was a young child, everybody was afraid. People didn't sit together in the coffee shops, in the meunasah (prayer house); they sat inside their houses. People were afraid of being suspected, interrogated, arrested. People stayed at home and recited Qur'an at night instead of going outside. When I asked my father, "Why isn't the light on in the mosque?" he replied, "We don't ask questions like that."

Although such heightened terror was a common experience in many black zones, and while all of my interlocutors had their lives disrupted by the conflict in various ways, most did not experience the conflict as a thirty-year period of terror. And while fear (takut) was a common emotion, it was by no means the only emotional state my respondents described in their narratives. Rather, most described the conflict as an 
extended period of "being suspected," which was punctuated by brutal acts of violence, and characterized by increasing forms of military intrusion into everyday life, slowly collapsing economies, restricted mobility, and the gradual expansion of the conflict to encompass more people and places. In addition, they described a wide variety of emotional experiences they felt as the conflict eased and intensified, and expanded and contracted over time.

\section{Surveillance and the Affective Climate of the Conflict}

Safrina's experience reflects the observations made by many anthropologists who have examined the destructive effects of violent conflict on everyday life. Anthropologists working in diverse ethnographic settings have illustrated that violence greatly disrupts social life, and that fear often breaks apart social relationships. More controversially, researchers have argued that fear defies expression through language, and produces what Taussig terms "epistemic murk," where violence produces deep uncertainty that breaks down everyday modes of understanding the world..$^{33}$ Das argues that fear defies language, so that people descend into a world of metaphor to describe pain and suffering. ${ }^{34}$ Skidmore argues that extended periods of terror come to dominate temporal experience and interrupt the ability of people to imagine a world without violence..$^{35}$

When heightened terror continues over an extended period of time, such fear can have a broad range of social effects. Green describes the effects of protracted violence as "fear as a way of life," where fear comes to saturate everyday life, first mediating then ultimately rupturing social relationships. She argues that while the emotional experience of fear becomes familiar over time, that fear never becomes truly normalized, but, rather, that the destructive effects of chronic fear become more deeply embedded into social life. According to Green:

Fear destabilizes social relations by driving a wedge of distrust within families, between neighbors, among friends ... The spectacle of torture and death, and of massacres and disappearances in the recent past have become more deeply inscribed in individual bodies and the collective imagination through a constant sense of threat. ${ }^{36}$

In many ways, my interlocutors' narratives resonate strongly with the accounts given by Green, Das, and many others writing about surveillance and terror. Like Safrina, a number of my respondents recalled feeling afraid (takut), and described to me how this ongoing fear came to interrupt everyday life. Protracted periods of terror,

\footnotetext{
${ }^{33}$ Michael Taussig, "Culture of Terror-Space of Death. Roger Casement's Putumayo Report and the Explanation of Torture," Comparative Studies in Society and History 26, no. 3 (1984): 492.

34 Veena Das, "Language and the Body: Transactions in the Construction of Pain," Daedalus 125, no. 1 (1996): 67-91. Many other prominent anthropologists have proposed similar arguments using different theoretical approaches. See, for example: E. Valentine Daniel, "The Individual in Terror," in Embodiment and Experience: The Existential Ground of Culture and Self, ed. T. J. Csordas (Cambridge: Cambridge University Press, 1994), 229-47; Marcelo M. Suárez-Orozco, "Speaking of the Unspeakable: Toward a Psychosocial Understanding of Responses to Terror," Ethos 18, no. 3 (1990): 353-83.

35 Skidmore, "Darker than Midnight."

${ }^{36}$ Green, "Fear as a Way of Life."
} 
such as Safrina describes for her village, can transform the meanings of everyday spaces and social interactions, as a familiar intersection transforms into a site of potential ambush, or a family owned vegetable plantation becomes seen as both a vital source of livelihood and a potential graveyard. Skidmore describes this reconstitution of social space as a process of "deterritorialization," through which formerly familiar social spaces come to be seen as strange, unknown, and unsafe. ${ }^{37}$ Worse still, friends, family, and neighbors may begin to fear one another as possible threats, or even fear that they themselves may inadvertently incriminate their loved ones if they are seen speaking to the wrong stranger. In times and places that were characterized by extreme fear, the everyday effects of this fear were felt as great losses and an intrusion on the ability to carry out valued social interactions that are seen to be integral to everyday life. This occurred, for example, when people less often went to the mosque together and became reluctant to engage in small talk on the streets for fear that they might be seen by a soldier and "suspected." Similarly, many recalled experiencing extreme fear during peak military operations.

However, fear was only one of the many affective states that conflict survivors described in their narratives. In addition to feeling outright fear, many also described a strong sense of being emotionally estranged from their villages and neighbors-which many described as feeling tidak betah "not feeling in place at home anymore." That widespread feeling of being tidak betah was closely wound up in sweeping, as it resulted from the ongoing intrusion of the security forces into everyday life. This estrangement of people from everyday social space was closely associated with roadblocks, arbitrary questioning, and door-to-door checks, together with corpse display, the "taking" of people from their homes and off the roads, and other modes of violence that militarized familiar social spaces. Many of my interlocutors described the feeling of tidak betah with great sadness, while those who still felt "in place at home" were proud of retaining this important connection with people and place, and the closely related sense of feeling brave and close to others.

The uneasiness and loss of connection to people and place that many conflict survivors described as feeling tidak betah is closely wound up in a sense of "being suspected." I suggest that this feeling was a direct result of the continual intrusion of the military into everyday life, and the reconstitution of everyday social spaces into signs of the conflict. Many of my respondents recalled that during DOM, "everybody was considered to be GAM" (dianggap GAM) or "suspected as GAM" (dicurigai GAM). It was widely understood that to be "suspected" carried an immediate threat not only to those individuals under suspicion, but also to their family, friends, and neighbors. While I met very few people who were afraid of their family members and close neighbors, many were afraid of strangers that traveled through their villages, and of "disturbances" (gangguan) that were seen to be committed by "unknown persons" (orang tak dikenal, commonly referred to by the acronym OTK). Many were afraid of direct retribution if the security forces suspected that they, their families, or even entire villages were sympathetic to GAM, or by GAM fighters if they were seen to be disloyal to GAM.

${ }^{37}$ Skidmore, Karaoke Fascism, 25. 
While many of my interlocutors received direct threats, many others regulated their own everyday actions to prevent themselves and others from being suspected. This had a wide range of social implications. For instance, many recalled that during peak periods of conflict, people less frequently went to the mosque together; rarely organized collective religious practices, such as zikir (reciting the ninety-nine names of God); and increasingly prayed alone. Importantly, zikir and other collective religious practices are common methods through which many Acehnese seek to generate positive emotional states such as feelings of being tranquil (tenang) and calm (puas), and of feeling a sense of release (lepas). Many also said that during periods of heightened surveillance they rarely held ritual feasts (kenduri), which would usually bring together neighbors and extended family from across Aceh. Some of the conflict survivors I interviewed were prevented from holding funerary feasts (kenduri mati) for their deceased loved ones, either due to direct threats from soldiers or a generalized fear of soldiers. This was extremely distressing for those families and increased their sense of estrangement from their village. Some said that they were afraid to offer hospitality to travelers during the conflict and that it became dangerous for men and travelers to sleep in the meunasah (prayer house). The ability to travel freely, to offer hospitality to strangers, and, for men, to sleep in the meunasah, are valued cultural practices, and my respondents recalled how these vital activities were interrupted or prevented by the conflict. ${ }^{38}$ Some told me that during periods of heavy surveillance their villages rarely met for meetings, and as a result interpersonal disputes often arose from misunderstandings. When people no longer felt close and at home, the village head (geucik) had difficulty mediating interpersonal disputes, and some villages lost faith in their village head, which in turn undermined a sense of feeling close to others and an ability to feel "in place at home."

While certainly closely related to fear, I argue that it is important not to translate all of these affective states into the English term "fear," but rather to attempt to understand the gradations of fear our interlocutors describe, the other more subtle emotions they express, the cultural significance of these emotional states and their impact on social life, and the various responses that people bring to these affective states. As Rosaldo describes, emotions are "embodied thoughts seeped with the apprehension that 'I am involved."' 39 Very often emotion involves a recognition that what is at stake is not only the personal safety of an individual-though this is obviously important-but also the ability of a person to engage in a wide range of valued social relationships. In the case of Aceh, these feelings of fear, estrangement, and being suspected were experienced in sharp contrast to idealized forms of Acehnese sociality, where people commonly aspire to feel solidarity or closeness with others, to be open (terbuka) in their exchanges with others, and to feel strong, tranquil, and brave. Although these are clearly idealized states of being, the conflict significantly undermined the ability of many to realize these valued states of being, at least in highly militarized spaces, and during periods of escalating tensions.

\footnotetext{
38 See James Siegel, The Rope of God (Ann Arbor: University of Michigan Press, 1969)

${ }^{39}$ Michelle Z. Rosaldo, "Toward an Anthropology of Self and Feeling," in Culture Theory: Essays in Mind, Self, and Emotion, ed. Richard A. Shweder and Robert A. LeVine, (Cambridge: Cambridge University Press, 1984), 143.
} 
While I suggest that the security forces intended to generate terror and social division and to control mobility through sweeping, and while this did occur at peak periods of conflict and in targeted spaces, sweeping also worked in many instances to undermine the credibility of the security forces and to inform a wide variety of responses to the conflict. Even while conflict survivors narrated the negative implications that sweeping had on their families and communities and the excessive force that was wound up in the practice of sweeping, the same stories of sweeping also reveal much about the limits of power of the security forces, especially in their attempts to control rural social space through surveillance. Because sweeping so directly impacted upon people's ability to carry out simple but valued everyday cultural practices such as praying together, talking freely in the streets, and traveling with ease to market towns and to visit extended family across the province, sweeping eventually became a focal point for resistance. In addition to fear, sweeping sometimes generated positively valued emotions since it drew attention to the cultural values and everyday practices that were inhibited by conflict, and this generated feelings of empathy and closeness with fellow Acehnese.

For instance, some of my respondents described how the intrusion of soldiers into their homes and everyday activities generated a sense of being "of the same destiny" with other Acehnese. This made many feel proud, strong, and brave. It also commonly inspired a sense of injustice (rasa ketidakadilan) that undermined trust in soldiers and government officials, and instead motivated some conflict survivors to offer care and protection to others. While women such as Safrina described the dramatic breakdowns in social interactions that occurred in a village targeted as a "black zone," others, such as the women I interviewed from bukit janda, described a heightened sense of mutual support and solidarity as a result of being so strongly targeted by the security forces. This strengthened their personal resolve and their sense of feeling close with others. Similarly, others described traveling through Aceh, observing roadblocks, and empathizing (merasakan) with those living in highly militarized spaces-whom they correctly imagined as being unable to carry out many of the everyday activities that they themselves valued and saw as integral to village life..$^{40}$

\section{Reading the Conflict Landscape}

While the early 1990s saw a period of intensified violence, the second half of the 1990s was not characterized by peace, but by sporadic acts of violence, high levels of sweeping, and a continued sense of "being suspected." Door-to-door checks and other forms of surveillance continued throughout DOM, and, indeed, until the end of the conflict in 2005. Military checkpoints were established at roadblocks throughout Aceh, and were particularly common along the Banda Aceh-to-Medan highway, which is the only road connecting major towns along the north coast, and an essential road for transporting goods and people into and out of Aceh. At roadblocks, people were

${ }^{40}$ These forms of terror did not dominate social life for the entire period of the conflict, as is often suggested in ethnographic studies of violence. For example, Dickson-Gómez argues that the anthropology of violence has been too strongly informed by assumptions about trauma, particularly the notion that trauma induces speechlessness and an inability to comprehend experience. See Dickson-Gómez, "One Who Doesn't Know War, Doesn't Know Anything: The Problem of Comprehending Suffering in Postwar El Salvador," Anthropology and Humanism 29, no. 2 (2004): 145-58. 
routinely stopped and questioned about their movements, their knowledge of rebel activity, and why they wanted to enter a conflict zone. As roadblocks aimed to curtail mobility, those living, trading, or traveling along major roads connecting market towns were commonly subjected to sweeping. Likewise, those living or traveling along smaller roads leading toward the foothills and mountains, which were seen as the center of GAM's guerrilla warfare, were also subjected to sweeping. The mobility restrictions imposed by sweeping strongly impacted upon small traders, who found it difficult to make a living (cari rezeki). A very common protest I heard from conflict survivors was "we couldn't go anywhere, it was hard to make a living!" (nggak bisa ke mana mana, susah cari rezeki!). In many areas, plantations and rice fields fell into disarray and local economies collapsed as a result of mobility restrictions imposed by sweeping.

However, since much of Aceh's largely rural population relies heavily on farming and small trade to make a living, many persevered and traveled through the conflict zone despite the difficulties and dangers. For example, Soraya, a woman in her $70 \mathrm{~s}$ from North Aceh, worked for many years selling vegetables at a market town on the main Banda Aceh-Medan road. She lived in a village a few kilometers inland from this town, and regularly traveled along dangerous roads between her village, the plantations where she sourced her vegetables, and the market town. Soraya told me that she understood the conflict "by looking around me at the environment, by being patient, and by never getting angry." Since she "wasn't brave enough to speak" to others to find out news about the conflict, she relied heavily on visual cues to interpret the conflict. For Soraya, sweeping, roadblocks, and the flow of people and traffic became visual cues through which she could understand the conflict. She would stay at home on days she thought would be dangerous. When at the market, she would carefully observe which of the other vendors had come to town that day. She knew the other traders well, including their home villages, the plantations they usually sourced their supplies from, and the roads they traveled on to go to market. She made a point to always take careful note of who was at the market, and who was absent. She noticed which minivans passed through town, whether the traffic was heavier or lighter than usual, and whether the minivans were full or empty. From these observations she assessed which roads had likely been subjected to sweeping that day and whether it was typical or heavy sweeping, and from her evaluation she anticipated whether there were any military operations in a particular area. She used this information to decide whether to stay at home and prevent her children from going to school on days she saw as dangerous, or to venture out on days she decided were relatively safe.

This tendency of Soraya to continually read the conflict landscape could be seen as an embodiment of insecurity, as often occurs during periods of protracted political violence. ${ }^{41}$ However, Soraya herself saw all of this as vital information through which she interpreted the dynamics of the conflict in her district without needing to risk implicating herself or others by directly having a conversation about the conflict:

\footnotetext{
41 See, for example: Green, "Fear as a Way of Life"; and Doug Henry, "Violence and the Body: Somatic Expressions of Trauma and Vulnerability During War," Medical Anthropology Quarterly 20, no. 3 (2006): 379-98.
} 
If anybody asked me a question, I would say "I don't know anything, I don't know anything." But I did know. But I didn't know from people directly. I could see from watching the environment.

While this seems a precarious source of information on which to make such important everyday decisions, in a climate of fear these visual cues of safety and danger became greatly valuable. In her work in Maluku, Spyer coined the term hyperhermeneutics to describe the process through which people living in times of protracted conflict become attentive to even apparently trivial occurrences around them, and transform these observations into signs of safety or danger. ${ }^{22}$ While this continual anticipation of violence may be grounded in a deeper uncertainty about how to interpret events around them, such calculations also inform a vital sense of agency and can greatly influence the responses people bring to conflict experiences. Soraya's observations about sweeping might seem a precarious basis on which to make potentially life-changing decisions. But she, and many other conflict survivors I interviewed, did not feel uncertain about these observations, but expressed confidence in the actions that they took that were based in their own observations of the shifting atmosphere of the conflict. Because sweeping was visible, people like Soraya could use it as a sign to interpret the conflict landscape, especially during peak military operations when talking and asking directly about the conflict was especially dangerous.

For many others, this feeling of being "not at home anymore" led people to leave their villages and seek out new homes in places they hoped would be safer. Although sweeping aimed to restrict mobility, it very often contributed to displacement as people sought out safer places to live.43 Many of my respondents had moved their entire families several times throughout their lives in a bid to find a safer place to live. For instance, one woman recalled how her parents moved their entire extended family from Sigli to Banda Aceh after her brother was intimidated by soldiers who often showed him photographs of their torture victims, attempting to force him to laugh at and admire their torture techniques. Several years later, however, the conflict had already expanded to impact their new home near Banda Aceh. Another moved her family from Pidie to South Aceh in the hope of finding a place without sweeping or "disturbances," and where she could more easily make a living as a small trader. But in fact she found that South Aceh was more militarized than she had realized, and she continued to face economic hardship and many other forms of violence, and moved several times before finally moving to Aceh Besar. Many others moved to "look for work (cari rezeki)," or to live in a place with more viable economies as rural economies began to collapse.

${ }^{42}$ Patricia Spyer, "Fire without Smoke and other Phantoms of Ambon's Violence: Media Effects, Agency, and the Work of Imagination," Indonesia 74 (October 2002): 35.

${ }^{43}$ Aspinall illustrates that while large numbers of Acehnese were forcibly displaced by conflict protagonists, that displacement also became a tactic for Acehnese seeking a safer or more prosperous place to live, attempting to outwit authorities, or for combatants wishing to develop international support networks. See Aspinall, "Place and Displacement in the Aceh Conflict." 


\section{Expanding the Conflict Zone: The Military Emergency}

While my interlocutors from the north coast districts described sweeping as a persistent feature of the conflict beginning in the DOM years during the 1990s, those from South Aceh, the West Coast, Aceh Jaya, and Aceh Besar remember when sweeping first affected their communities as the conflict expanded after 1998 to incorporate these new districts. Political tensions surrounding the future of Aceh escalated after the fall of President Suharto in 1998. By this stage, GAM had developed a sizable popular support base, the credibility of the central government was in question, and a vibrant activist movement had developed in Aceh that was bringing attention to injustices committed in Aceh and that called for a referendum on the question of independence. ${ }^{44}$ Two failed attempts at peace negotiations in 2000 and 2002 were undermined by a number of factors. The security forces continued to commit acts of violence, including the forced displacement of civilians, while GAM refused to compromise on its claim for independence. ${ }^{45}$ The conflict intensified and expanded dramatically in May 2003, when President Megawati Sukarnoputri declared martial law in Aceh and fighting expanded to incorporate most parts of Aceh. ${ }^{46}$ Jakarta once again sent in additional troops, so that in 2003 a total of twenty-eight thousand soldiers and twelve thousand police (including heavily armed counterinsurgency units) were fighting against approximately five thousand GAM fighters possessing an estimated two thousand weapons. ${ }^{47}$ The conflict rapidly intensified, and many Acehnese described 2003 as the worst year of conflict. Even now it is common for Acehnese to refer to this period of time as "the conflict."

Soon after the introduction of martial law, the security forces announced that all Acehnese would be issued with new identity cards (Kartu Tanda Penduduk, KTP), and that everyone would now be obliged to carry the card at all times. The new identity cards would be colored red and white, the colors of the Indonesian flag. The security forces claimed that this decision was a means to replace cards that had been stolen by GAM.48 This measure, however, also forced all Acehnese to report to the authorities, where they were questioned about the movements and whereabouts of their families and neighbors. ${ }^{99}$ Since identity cards could only be replaced in a person's home district, the thousands of Acehnese who by this time were living outside their home districts, either through voluntary mobility or forced displacement, were placed in the precarious position of needing to travel home through conflict-affected areas without a valid identity card.

${ }_{44}$ On Acehnese NGO responses to the conflict, see Paul Zeccola, "The Dilemmas of New Humanitarianism: NGO Responses to the Separatist Conflict and the Indian Ocean Tsunami between 1998 and 2008 in Aceh, Indonesia" (doctoral thesis, Australian National University, 2011).

${ }^{45}$ For a detailed analysis, see Edward Aspinall and Harold Crouch, The Aceh Peace Process: Why it Failed (Washington, DC: EastWest Center, 2003).

${ }^{46}$ International Crisis Group, "Aceh: How Not to Win Hearts and Minds" (Asia Briefing 27, International Crisis Group, July 23, 2003).

${ }^{77}$ Human Rights Watch, "Aceh Under Martial Law: Inside the Secret War" (Human Rights Watch report, "Aceh Under Martial Law," December 17, 2003): 12, available at https: / www.hrw.org/ report/2003/12/17/ aceh-under-martial-law-inside-secret-war, accessed September 14, 2015.

48 Ibid., 33-39.

${ }^{49}$ Ibid., 33-37. See also International Crisis Group, Aceh: How Not to Win Hearts and Minds, 2. 
For those living along the north coast, this was an escalation of the sweeping activities that had been underway since the early 1990s, which restricted their mobility and acted as a common form of military intrusion into their lives. For others living in Aceh Besar and Aceh Jaya, this expansion of sweeping acted as an ominous sign that they, too, were now suspected. Many people from Aceh Besar, Aceh Jaya, and other districts of Aceh were less familiar with GAM, and often described GAM fighters as "provocateurs," "unknown persons," or "outsiders" from "across the mountains." Around the same time that the new identity cards were introduced, there was an increased visibility of roadblocks and checkpoints in areas that had previously been considered outside of the conflict zone.

Lena, for instance, described the escalation of sweeping into Aceh Besar as follows:

In Aceh Besar before the conflict, it was perfectly safe. But after the conflict took hold, after 1999, every day we had sweeping. During the conflict our identity cards [KTP] became our life spirit (nyawa). For we Acehnese, the number-one thing was our identity card. If we didn't have an identity card, we were considered to be that-separatists. We had to have the red and white card. During the conflict, the identity cards were red and white. If we didn't have an identity card, that meant that we couldn't go anywhere, that we would be taken if that occurred, taken by the military, because if we didn't have an identity card, we were considered to be GAM. Lots of people became victims like that. Even if they had an identity card, if they got on their motorbike, if they dared to leave the village, they were taken.

Another woman I interviewed from Aceh Jaya also described the ways in which sweeping expanded into her home district, and greatly disrupted her life. In telling me her life story, she asked me not to give her an Acehnese women's name as a pseudonym but instead to call her "Inong Ojek" (motorcycle taxi woman), since she was afraid that another woman with the name of her pseudonym may be implicated by her choice to tell me her story. An unusual occupation for a woman, this was how Inong Ojek made a living during the final years of the conflict. Inong Ojek told me how, during the 1990s, the conflict seemed far removed from her life. She knew of the conflict only through people who "crossed over the mountains" on migratory work (rantau), bringing with them stories of the conflict on the north coast.

Inong Ojek and her husband made a living working in the vegetable plantations on the foothills near her house. After 1999, sweeping began to be a common sight on the road connecting Inong Ojek's village to the main road. It became increasingly difficult for her and her family to access work in the plantations, or to go to Banda Aceh or Meulaboh to buy supplies and visit family. They became poorer and slowly became more isolated from neighboring townships. She and her neighbors began to regularly hear the sound of gunfire coming from the foothills behind her village.

Her involvement in the conflict escalated dramatically one night in 2003, when soldiers came to her home in the middle of the night and took her husband and son.

I was shocked. We were sitting in our house in the middle of the night. Three men came, came and took my husband and took my son. I didn't know the name "GAM" and suddenly my husband and son were suspected as [being part of] GAM. 
They were interrogated and beaten, and returned home badly bruised the next day. It was at this point that Inong Ojek made the decision to "order" her husband and son to stay at home, and she took up the sole responsibility for finding an income (rezeki) for her family. ${ }^{50}$

The vegetable plantations they used to work in had now been almost completely abandoned, so that her family no longer had an income from this plantation. Since her son owned a motorcycle, she decided that the most viable way to make money would be to become a motorcycle taxi (ojek) driver. She began transporting people from her village into the main town, approximately ten kilometers away. However, the dangers of her new occupation soon became apparent. It was not long after she became an ojek driver that GAM fighters also began to threaten her family. GAM fighters forced her to transport ammunition from the coastal town to the foothills, promising to provide protection for her family if she complied, while at the same time threatening to kill her family if she refused. Meanwhile, the security forces continued to watch and question her husband and son who were still "silent" after being taken and beaten. "In my case, I was threatened by GAM and I was threatened by the TNI, too," she said.

Inong Ojek's work as an ojek driver meant that she was on the roads every day. Since she had to pass through roadblocks daily, she became known to the soldiers who carried out sweeping on the small road connecting her village to the main road. The GAM fighters in the area also watched her closely. After she passed through a sweeping checkpoint, or when she was observed being questioned by TNI soldiers, GAM fighters would then approach Inong Ojek, threatening to kill her family if she informed on them. Since she was regularly stopped in sweeping and often searched, she was frightened that she would eventually be caught transporting ammunition. She seemed surprised when she told me that the soldiers never did catch her with ammunition.

She told me that she felt ashamed (malu) of driving a motorcycle taxi "like a man," but that she was also proud that she made this decision:

I am not brave like typical Acehnese women. But when my husband and son were taken and beaten, I had to be brave. Now I can say it's true. I am a brave Acehnese woman.

For Inong Ojek, as for many others, sweeping was a point of continual threat and intrusion in her daily life, a barrier that restricted her ability to carry out everyday activities, and a sign that the area that she lived in was now "suspected." Her response to sweeping, and to the conflict in general, ultimately enabled her to survive the conflict with her pride intact, although her choices also exposed her to great danger.

For Safrina and many of my other interlocutors from the rural north coast, sweeping was closely tied in with the forms of terror used during DOM. It was a strategy used by the security forces from the very early days of the conflict, and one

\footnotetext{
${ }^{50}$ Many explained to me that, since men were likely to be "suspected" by soldiers, women often ordered their husbands and sons to stay at home and they themselves became more mobile in "looking for rezeki" outside of their villages. While my interview data suggests that both men and women were mobile during the conflict, this recurring narrative reveals both the widely held belief that young men would be taken away and killed, and the great risks women took in increasing their own exposure to violence in a bid to protect and feed their families.
} 
replicated by GAM in the later years of the conflict. In contrast, Inong Ojek and many of my respondents from other parts of Aceh remember sweeping as suddenly appearing in the landscape after 1999, and rapidly escalating during peak military operations in 2003. Sweeping was widely taken to indicate that "everybody was suspected as GAM." Sweeping was clearly understood by conflict survivors as a method used to control people's movement through areas that were perceived as being sympathetic to GAM. People like Inong Ojek, who became suddenly mobile, were "suspected" and faced many forms of violence, as did people like Safrina, who were simply walking to school along a dangerous road in a black zone.

\section{Sweeping: Creating Terror and Informing Resilience}

This article has taken up a discussion of the surveillance strategy known as sweeping in order to show how this mode of violence shaped the spatial-temporal dynamics and the affective climate of the conflict. Sweeping built on preexisting imagery that associated GAM with the rural landscape, before building a range of surveillance practices that militarized social space, especially villages in rural Aceh. The spatial-temporal effects of sweeping intensified in particular times and places to create black zones, while the overall conflict zone gradually expanded over time as the conflict continually eased and intensified and as more Acehnese became "suspected." As has been demonstrated by many anthropologists discussing the effects of surveillance, I have argued that sweeping was, in fact, intended as a terror strategy to militarize social space, to restrict mobility, to break down local economies, and to destabilize everyday life by inducing widespread fear. To a great extent, sweeping did generate fear and inhibited the ability of ordinary Acehnese to participate in social life. The destructive effects of sweeping were particularly apparent in black zones, during peak periods of political violence and to villages that could easily become isolated through sweeping.

I have shown, however, that my interlocutors did not only experience heightened terror, but a range of emotional states that continually shifted as the conflict escalated and de-escalated over time, and expanded and contracted into different social spaces. I do not intend here to downplay the destructive effects of the conflict. Acehnese people suffered greatly during the GAM conflict, due to systematic abuse by the security forces, and due to threats and extortion by GAM fighters that were directed toward those who did not support GAM. The point rather is to show that surveillance can produce a wide range of emotional states, and that over time these emotions shaped people's everyday responses to violence, and the dynamics of conflict as it developed over time. While sweeping may not have been the most horrific mode of violence experienced by conflict survivors, it was a persistent form of violence that had significant social, emotional and economic impacts on Acehnese society, that led particular communities to feel targeted and become dislocated, and that was widely experienced as an intrusion into everyday life. Sweeping reveals much about what it means to live in a sporadic conflict that continually shifts and transforms over time, leading to periods of intense fear, times of relative ease, and ongoing uncertainty about the future. It is for all of these reasons that sweeping featured so strongly in the narratives of conflict survivors in 2009, as they began to seek justice, to rebuild 
76 Catherine Smith

livelihoods, and to bring about the many social transformations necessary to recover from decades of conflict. 